\title{
Improvised Performance in World Music: Finding the Violin in Unexpected Places
}

\author{
Jonathan Feig
}

\begin{abstract}
Since 1980, (Sonny) Rollins has made more than a dozen recordings in the studio, but, unlike many of his fellow titans on the tenor saxophone... he has realized his talent almost exclusively on the bandstand. (Stanley Crouch, 2005)

Are you a reading fiddler, or a jamming fiddler? (Question posed to the author by Cleveland Eaton, Birmingham Alabama based bassist and bandleader, spring 1998)

This chapter focuses on improvising violinists, but its framework offers a way to explore the work and potential of all featured performers within the area of live music performance. By examining the work of six violin players, I pose and examine questions that are essential in the production and promotion of any music. The questions relate to the two following areas:
\end{abstract}

1. the performance psychology, and

2. the market categorization of the music

The first area refers to a musician's psychological inclinations and social skills that influence his work and role in a group. The second area refers to the marketing categories of music that tend to function as stereotypes, orienting industry and audience expectations of what a music and a musician should sound like. 


\section{Performance Psychology}

There are a variety of ways that a musician can be presented on stage, depending on the variety of sub-skills (both musical and social) he may possess concerning the following set of issues:

- Leading/ Collective Behavior/ Following

- Conducting, Arranging/ Jamming

- Regular band/ Rotating personnel

- Production/ Sound Management

The questions that I will explore here, and that I think any producer and promoter should ask about featured instrumentalists or vocalists are the following: Is the performer in question most comfortable in the role of a leader? Is he capable of collaborating with other musicians as an equal partner? Would he or she be most comfortable in the role of a sideman, but receiving copious amounts of solo time within the structure of the band, whether it was a concert band, dance band or some other musical situation? Does the performer prefer a regular body of work, expanded upon over time, or a regular performing ensemble? Or would he or she play best calling tunes out of the air, engaging in open or free jam sessions, or rotating the other band members as much as possible to keep the energy fresh?

I will argue that of the six violinists to be examined, Gatemouth Brown, Alfredo De La Fe, and Simon Shaheen are all (or are in the process of becoming) great bandleaders, while L. Shankar is an incredible collaborator. Chombo Silva, for his part, was a sideman who should have been presented more often as a featured soloist, without necessarily being asked to front bands. Claude Williams was an able sideman, who met the demands of fronting a band for the last twenty years or so of his life, but he might have been more comfortable as a sideman, taking extended solos within the context of a regular working band featuring other artists equal in stature to him.

\section{Market Categorization of Music}

I will also examine the impact of global and local stereotypes and labels, such as World Music or "race music" on the promotional potential of particular performers. The violin will be used as a jumping off point for discussions of the stereotypes. Violin can be used to highlight a variety of assumptions that we have about different types of music and the musicians who perform them. 
While the violin, as we know it today, is a turn of the eighteenth century northern Italian version of a type of instrument that is familiar and common in musics around the world, the main global assumption about the violin is that it is primarily a European instrument. This is in part due to the aesthetic power of the work of great European composers (primarily German) from the seventeenth to the nineteenth centuries, for whom the violin was a favored vehicle for their concerti, symphonies and sonatas. But as I will show, it is also based on artificial categories invented by the American recording industry within the context of "race music" in the beginning of the twentieth century as a way of selling records without running afoul of the apartheid-style Jim Crow racial laws in the United States. Categories have helped to launch the absolutely false ideas that modern brass instruments (primarily invented in Europe in the eighteenth and nineteenth centuries) are somehow African in origin and that the violin (even though an inherent part of all human music culture in one form or another for millenia) is a European invention and usable in the context of European music.

In Indian and Cuban music, the violin was traditionally a rhythm section instrument, used to back up the work of flautists and singers. ${ }^{1}$ How was it then that L. Shankar was able to move the violin to the front of the band, together with Zakir Hussain and others, while simultaneously staying within the context of traditional or classical south Indian music? And how can Alfredo De La Fe combat both local and global assumptions that make it challenging to present his violin work as a featured part of a salsa presentation? While the stereotypes and assumptions within the Cuban music community indicate that the violin is a background instrument, non-Latin American fans of Cuban music or salsa are not even aware of the existence of the violin within Cuban music at all, probably because of sub-conscious (and false) assumptions that the violin is an inherently European instrument, and has no place in Afro-Cuban music.

Similarly, the term World Music is nothing more than a generic brand. It is a brand for marketing sounds, which promoters and public alike deem to be Other, that is, alien to the locale where it is being presented. I think the World Music category and the stereotypes that come with it can be productively used in marketing. The main pitfall of the label is, however, the image that it presents "traditional" music to a "modern" audience.

Rather than traditional, I will show that certain musical structures, such as ragas, taqasim, various blues forms and the descarga, are simply timeless. In response to Joe Boyd's statement (in this volume) that World Music audiences are attracted to the sounds that are "acoustic, virtuoso and backward-looking", I would like to emphasize that the marketing strategies of the music should acknowledge that

1 "Visionary Violinist". Hinduism Today. March/April 2001. « http://www.hinduism-today.com/ archives/2001/3-4/19_1_shankar.shtm/>>. 
"traditional" musics are living, breathing organisms that are capable of evolving over time, no less so than European classical music or British pop. This means acknowledging and giving room for innovation within the specific traditions and fusions with other musical streams. The problem inherent in the stereotypes and music categories is the notion that "Western culture" is modern, dynamic and open to innovation and change, while "traditional" cultures and World Music are static, frozen in time, and stuck in some sort of eternal past. There is nothing inherently backward-looking about jamming on a talam, for instance, even if this timeless form may have been invented 500 years before J. S. Bach. Indian violinist L. Shankar makes this quite salient when he says:

Certain things are only possible in certain places. For instance, like making the double violin. It was only possible to have it made in America... Now I have written a lot of new compositions. All my recordings in the last 20 years have been using new ragas and new talam cycles. ${ }^{2}$

Shankar needed to go to America to get a particular piece of hardware manufactured. But his wildly innovative performance style is an example of the potential for innovation within the discipline of carnatic, or South Indian classical music.

To further elaborate on this I refer to an article by Hansen (2004), concerning the ethnic identity of the Ainu minority in northern Japan. Hansen starts from the problem that as a people with no written tradition, the Ainu, like Edward Said's (1979) Orientals, have been subject to the description and categorization of their cultural attributes without actually having been given permission to participate in the explanations of their cultural identity as these were being generated by a variety of non-Ainu sources. Furthermore, in the descriptions of Ainu society (mostly generated by Japanese), the Ainu are only seen as being truly Ainu if they, for example, dress in animal skins, engage in traditional hunter/gatherer behaviors, and move about on foot, or in traditional small boats. So that as soon as the Ainu put on a shirt, or drive a car, or attend a university, (non-Ainu) anthropologists assume them to be "turning Japanese" or simply assimilating. Perhaps we had better acknowledge that even if an Ainu is wearing a shirt and driving himself to the local university, he is still an Ainu, and if he goes out to sing Karaoke afterwards, he can be authentically himself and partly Japanese, like the rest of us, without losing his authentic cultural identity as an Ainu.

I hope that the reader walks away after reading this chapter with a sense of the greatness of the artists under discussion, but even more importantly, that it gives him or her a way out of some of the boxes that stereotypes about music and musicians have left us stuck in. Looking at these issues through the lens of two

2 "Visionary Violinist", 3. 
generations of performing/ improvising violinists, coming from four areas of world music, I will argue that promoters and producers need to support the values and expertise of the individual performers they are producing. By values and expertise I refer both to choices about musical styles, traditions, innovation and fusions, and the acknowledgement of individual artists' interpersonal and musical strengths. Additionally, artists need to be promoted in ways that recognize the pre-existing stereotypes; these stereotypes can then either be strategically reinforced or negated in the promotional strategies (regardless of the truth-value of the stereotypes). The chosen strategy should depend on what best supports the individual artist in reaching the largest possible audience.

\section{Improvising Violinists from the 1930 s to the Present}

\section{Claude "Fiddler" Williams}

Claude Williams was born in Muskogee Oklahoma in 1908 and passed away in 2004. Williams started his career as a member of Ben Johnson's string band. He was also featured with the Pettiford family band that included the legendary bass player Oscar Pettiford. He moved to Kansas City in 1928 and is a veteran of jam sessions and of many great bands from this time and place, including Andy Kirk's Twelve Clouds of Joy, which also featured the piano, composition and arranging work of Mary Lou Williams. Before leaving Kansas City he was also a featured member of the bands of Alphonso Trent and George E. Lee. He then moved to Chicago where he became a featured member of Eddie Cole's band, which also featured the bassist's brother Nat on piano.

It was at this time, in 1936, that Count Basie came to Chicago looking for "the great guitarist and fiddler he remembered from Kansas City jam session". ${ }^{3}$ Claude was the original featured guitar player with the Basie band and appeared on the very first recording that they made. He won the downbeat readers' poll for best guitarist of the year for 1936. However, producer John Hammond chose to replace him in the Basie band with Freddie Green, who did not double on fiddle, and for Claude (but more importantly for fans of the violin in jazz and African American music) the opportunity was sadly lost.

To give Hammond the benefit of the doubt, it certainly must have been challenging to balance the sound of a violin with that of an entire horn and brass section but, since Claude was only taking solos on the violin (his rhythm section duty consisted 
of strumming the guitar), it would have been easy enough to bring down the dynamic for an occasional violin solo, as is the practice in traditional charanga settings.

With all due respect to the successful career of Williams and the important contribution that he has made, the understanding of the role of the violin in jazz might be very different today, if the Basie Orchestra, as one of the most important jazz groups of all time (also commercially) had featured even an occasional violin solo by a soloist of Claude's caliber during the years that Count and Claude were both alive. And with all due respect to the important work that Hammond did, both technically as a producer and socially in challenging the racist ways in which different styles of American music were (mis)categorized and marketed, I feel that Hammond was in fact perpetuating some subconscious myths derived from the notion of race music - namely that African American music, on the one hand, and the fiddle, on the other, were two mutually exclusive categories.

After leaving the Basie band in 1936, Claude performed with a variety of artists, including Austin Powell, Roy Milton and Eddie "Cleanhead" Vinson. Finally in the early 1970s he joined Jay McShann, and it was in combination with and in featuring the support of McShann that Claude was able to do his best work. At the end of his life Claude had the excellent support of manager Russ Dantzler, who managed to generate quite a bit of performance work for the great musician.

I would like to create a template for music producers and promoters working with performers. In this template I would posit Claude Williams as a personality type who functions better as a sideman than a leader. Claude Williams was shy and humble, which cannot be said, for instance, about Gatemouth Brown or Alfredo De La Fe. This regardless of the fact that Claude was a top-notch soloist; anyone who has ever heard his performance is wowed by his chops, imagination and energy level.

The questions that need consideration are: How can music industry people support the work of top-notch instrumental performers, who are not "alpha personality types?" Is it possible to support excellent solo instrumentalists in finding their niche in pre-existing orchestral situations? Or to help them find band members and bandleaders, who would be able to give them the structural support that they need to take fine solos (at least $20 \%$ of the performance time) and then lay back, relax, and be part of the band the rest of the time. I do not think that it is disrespectful to say that while Jay McShann was a great musician and a great bandleader, Claude "Fiddler" Williams was simply a great musician. 


\section{Clarence "Gatemouth" Brown}

Gate was born in 1924 in Vinton Louisiana and grew up on the Gulf Coast in Orange Texas. He began to work professionally as a drummer during World War II. Shortly thereafter he was leading a 23-piece band on tours across the south and southwest, which inspired his manager to form the first successful black-owned record label of the post-war period to further promote Gate's work. Gate then moved to Nashville, where a successful career in recording and television led to several decades of international tours, including a stint as musical ambassador for the US State Department. Since the 1970s Gate has led bands that have cut dozens of albums and featured as sidemen for such stars as Eric Clapton, Ry Cooder, Maria Muldauer and Leon Russell.

Gate leads bands. He busts musical categories within the context of American music, he writes and arranges tunes, and yet sometimes it feels like his gigs are just one big jam session. Is this true? Or is Gate just capable of generating such a relaxed atmosphere on the bandstand through his virtuoso abilities as bandleader and conductor that it just looks that way? This leads to a set of questions for promoters of musicians who might be in structurally similar if culturally different position to that of Gate: How much straight "jamming" should be presented in a particular venue? Should instrumental, improvised music be presented to mainstream audiences as a jam, or should the forms existing within each tradition or fusion of traditions be highlighted, also in the context of a staged show?

\section{Jose "Chombo" Silva}

Chombo Silva was born in Baracoa Cuba in 1913 and passed away in 1995, one year after suffering a stroke which deprived him of his ability to play. The greatest of the working charanga violin players on the North American scene of his time, together with Pupi Le Garrata, Chombo was also a phenomenal improviser on both the violin, and the tenor saxophone. After a childhood of music and music study in Cuba, in the 1950s he toured Panama, Madrid and Paris with the Penalver Brothers Swing Orchestra. He returned to Cuba in 1956 to participate in the legendary "Cuban Sessions" for the Panart label recordings, "which augured a new chapter of individualism in the world of Cuban Pop music", according to New York radio DJ, Chico Álvarez. ${ }^{4}$ Alvarez goes on to state that, due to the financial conditions in Havana at this time, it was not possible for soloists of Chombo's stature to achieve viability in the marketplace, and thus, like many other Cuban musicians of his generation, he relocated stateside.

4 Ernesto "Chico" Álvarez Peraza 2001. "Chombo Silva. A Tribute To The Magician of Baracoa”, Latin Jazz Network -webpage. Translated version at: $<$ http://www.latinjazznet.com/articles/ chombo_silva.htm >>. 
He worked and recorded with, among others, Cal Tjader, who referred to him as "the Latin Lester Young", ${ }^{5}$ and most importantly Mongo Santamaria, whose legendary work is available on $\mathrm{CD}$, and who provided Chombo with what was his best opportunity to showcase his chops, both on violin and saxophone. All available on the Fantasy record label, these include Sabroso, Mongo Santamaria at the Blackhawk, !arriba!, and Mongo's Greatest Hits. This classic ensemble, which also functioned as a template for many of the great North American charangas that came after it, was also really a classic Latin jazz ensemble, in that within and alongside the tightly structured and highly stylized arrangements and call and response patterns of the traditional charanga sound, there was also space for Chombo, as well as other members of the ensemble, to stretch out and improvise, without losing the rhythms or the forms of the traditional Latin music. After his work with Mongo, Chombo continued to work full-time, exclusively as a sideman, with such bands as Orqesta Ideal and El Siglo Venti, until he suffered a stroke in 1994. Jose "Chombo" Silva was a full-time sideman who was also, I think, the most important improvising violinist of the twentieth century.

The questions this raises are the following: What should producers do with performers who possess star-level chops and talent, but laid-back, "sidemantype of personalities?" What can promoters do when local stereotypes ("violin is a background or rhythm section instrument") and global stereotypes ("Afro-Cuban music does not use bowed stringed instruments") coincide, hindering the potential for generating visibility and viability for a performing artist?

\section{Alfredo De La Fe}

Alfredo De La Fe was born in Cuba in 1954, and like the other two improvising violinists of his generation whom I discuss, he was a child prodigy. Alfredo began his career as a professional classical musician, touring extensively in Cuba and Eastern Europe. He moved with his family to the United States in 1965 and began immediately performing full-time as a member of the charanga group, led by the renowned flautist Jose Fajardo. Fajardo was a traditionalist who did not allow for violin solos in his ensemble, but Alfredo spent a number of years with the band, absorbing information about the music of his native island that he perhaps had missed while studying European music in Cuba.

Later he worked with the charanga group led by Eddie Palmieri, a musical rebel like himself, so that this band, like the great orchestra led by Mongo Santamaria a generation earlier, was simultaneously a classic Latin dance-unit and a burning high energy jazz group. Immediately following this Alfredo co-founded and worked

5 Álvarez Peraza 2001. 
with the legendary Tipica '73, a band which also blurred the distinction between dance music and Latin jazz. Alfredo's place in the pantheon of great improvising musicians was thus already set at the age of 19 , but his work had only begun.

It is generally assumed that personal problems were the defining issue leading to Alfredo's exodus from the New York scene, and his 20 year odyssey in Colombia and Europe, but I think that what he was really guilty of was an intensity of talent and of personality, for which there was not enough room on the New York music scene of the time. For Alfredo's behavior at the end of the 1970s New York City was not all that different than anyone else's, it was just more extreme.

Alfredo, possessed of some of the best technical violin chops in the world, and being at the center of the New York Latin music and Latin jazz scenes, and being the personality that he is, has the potential to reach out to a wide variety of audiences, and to break down barriers between genres, in a way that Carlos Santana has done before him, provided that the promoters support him. Much has been made of Alfredo's personal issues, and while it was certainly tragic for the New York music scene that he was not around all those years, in the end, after Alfredo had triumphed his problems, New York's temporary loss was the rest of the world's and Alfredo's gain. The work that he was doing in Colombia and later in Europe certainly proved Alfredo's genius, both for expanding upon the beauty of traditional Cuban forms, and for fusing Cuban music with a whole panoply of other Latin music styles and genres. I believe also that leaving New York forced Alfredo to abandon what for him was really a crutch; that of working as a full-time sideman and collaborator in New York. Especially in Colombia he was able to come to terms with himself as a leader/ composer/ musical director, on a variety of scenes, as he found there were many musicians eager to work with him and support his legendary talents.

For a time in the 1950s, Tito Puente's band was the most popular dance band in the New York area. Then "white" people decided that they could only dance to rock music. Carlos Santana was one of the few Latin performers able to go with this trend. I believe that today, with the right promotional support, Alfredo, with his mix of violin chops, multiple level performance talent ${ }^{6}$ and his aggressively entertaining "alpha personality" could achieve the market success of a Santana. Alfredo would apparently have no problem dealing with promotion and marketing either, judging on the basis of the work he did in Colombia and Italy since the 1990s. The moguls of the World Music business should help him out.

6 Like Gatemouth Brown and Simon Shaheen, he is also a capable composer, arranger, musical director, record producer. 


\section{E. L. Shankar}

L. Shankar was born in 1950 in Madras in South India. He spent his early childhood years in Jaffna Sri Lanka, where his father was a professor of music, but was forced to flee with his family back to India when the family house was torched and various attempts made on his father's life during a period of communal violence. Shankar is the youngest of six children who all have at times worked professionally in the field of music.

A virtuoso and prodigy in both South Indian and European classical music, Shankar performed as a young child and a teenager as a sideman with many of the great names in Indian music. He moved to the United States to study and teach in 1969, and soon formed with John McLaughlin a collaboration, which led to the highly successful band Shakti. The group was around for a number of years, performing music that Shankar calls fusion, but that to my ears sounds more a pushing forward of the traditions of South Indian classical music, incorporating Western instruments, but sticking most of the time to the forms and formalisms derived at least in part from traditional Indian sounds. Shankar has since had a highly successful and widely varied career as a sideman and a solo performer with a variety of rock, art-rock, and fusion bands. Additionally, he has acted as the co-leader of a very stable south Indian classical music ensemble, which over the last twenty years has primarily consisted of the trio of Shankar, Zakir Hussain and Vikku Vinayakram, and now also features the work of the additional violin player, Ginger.

Shankar's ability to blend in has made it possible for this virtuoso performer to appear on stage and in recording studios with a wide variety of performing artists from a wide variety of cultures. In addition, the connections that the public and the promoters alike will make between traditional Indian culture, on the one hand, and the intersection of pop and new age cultures, on the other, has perhaps increased Shankar's ability to tour and record with a variety of pop and rock artists. However, in the long run I am not sure that these connections have improved Shankar"s visibility within the area where he is truly a genius; that of a small group ensemble performance and improvisation of carnatic music, in the company of Zakir Hussain, Vikku Vinakrayam and others.

I think that Shankar has done remarkable work to show that as a traditional performer of non-Western classical ("timeless") music, one can engage in a wide variety of experimentation without betraying the aesthetic values of one's musical forms to commercialism, on the one hand, or to conformity with the Western forms, on the other. What is fascinating about Shankar's performance work is that he always seems to be working collaboratively with other musicians, who are on equal stature 
with him, and equal partners in the project at hand. A joint venture with Zakir and Vikku started before Shankar achieved star status. Or even in a previous lifetime, as Shankar has suggested. ${ }^{7}$ But both in terms of technical support and production values, Shankar possesses an extremely nuanced and developed social intelligence, which allows him to coordinate together with other people in many musical ways, without having to dominate or control the situations of which he is a part.

In this context I would like to raise the following more general question: How can promotion and production people support the work of artists like Shankar who might be more comfortable working together with other artists rather than leading them, so that they can succeed both in terms of getting enough performance time, and of receiving acknowledgement for their solo improvisation chops?

\section{Simon Shaheen}

Simon Shaheen was born in 1955. He grew up in a musical family in Tarshiha in the Galilee. His father is a professional oudist and music teacher, and like Shankar and many of the other musicians surveyed here, he gleaned a great deal of his musical expertise from his family as a young child. He attended both music school and conservatory locally. After being chosen for the post of the professor of Arabic music at the Jerusalem Academy of Music, he was accepted for graduate studies at both the Juilliard and the Manhattan School of Music. He chose Manhattan because he felt at the time that it provided a more open-minded environment for someone who was both a student and a teacher of non-Western music.

For the last 25 years he has been based in New York, teaching and performing traditional Arabic music, as a violinist and oudist both with his own band Near East Music Ensemble (which features his brother Najib Shaheen backing him up on oud when he plays violin and vice versa) and simultaneously working on a variety of performance-based projects. Shaheen takes a split level approach to promotion, doing workshops, local gigs and even club dates with his regular band The Near East Ensemble, while additionally recording, performing and touring with more high profile ensembles dedicated both to fusions and to the preservation and innovation of Arabic classical music, such as the group Qantara on his CD Blue Flame, ${ }^{8}$ which seamlessly flows back and forth on various tracks between takes of traditional sounds (featuring Shaheen improvising on both oud and violin) and fusion tracks (which additionally feature the solo chops of other artists, as well as Shaheen's skills as an arranger, conductor and composer).

7 "Visionary Violinist", 3.

8 CD: Blue Flame. Simon Shaheen \& Qantara. Ark 21 Records. 2001. 


\title{
Production and Marketing Challenges of the Selected Violinists
}

\author{
Claude Williams and Gatemouth Brown: From \\ "Race Music" to "World Music"
}

It has been said that I am one of the greatest fiddle players in all of the south.

(Clarence "Gatemouth" Brown) ${ }^{9}$

Having grown up with the story about how John Hammond cut Claude Williams out of the Basie band, I have asked myself from time to time whether Gatemouth Brown uses his fiddle performances of country and western, cajun and bluegrass music as a marketing device to reach out to audiences who might not otherwise be sophisticated enough to appreciate his performances of jazz and blues on this instrument. But I realize that this question is simply based on the same subconscious racist assumptions, which may have led Hammond to make his historic decision concerning Williams.

Above I defined World Music as a marketing niche that includes any music that is alien to the market in which it is presented. American music is not usually included in this niche, because it is difficult to imagine a place at this point of time, where American music is alien enough to be considered as Other. However, an example of a definition of some music as Other is the "race music", a category created by the American recording industry at the beginning of the twentieth century to promote and sell recordings made by "negroes" at a time when white and black musicians were not legally allowed to work together in many parts of the United States without running afoul of the law. Starting from the category of "race music", a whole panoply of musical genres emerged; for example, cajun music, country and western, bluegrass, and many more.

Consequently, while blues and jazz have been accepted in the marketplace and in the consciousness of consumers and producers as being African American in origin, cajun music, country and western, and bluegrass are thought to be products of the "Euro-American" culture. This is not true, however. I would argue (especially after witnessing performances by Gatemouth Brown) that all of the music genres listed above can be conceived of as subgroups within a larger category of "Southern American music". Subsequently, any American musician - white or black - who (unlike Gate) has not achieved proficiency in all of these styles of music, is simply suffering from the effects of lingering racist assumptions implanted during Jim Crow and reinforced by the marketing strategies implemented

9 DVD: Clarence "Gatemouth" Brown In New Orleans. Track 11: Up Jumped The Devil. Trad. February 4, 1984. Storyville Records. 
at the end of that same period. These marketing strategies made it possible to sell records by black recording artists, but simultaneously forged categories of musical production, which were not only false, but divisive.

The great producer of "race music", John Hammond, who would also do a great deal to move the recording industry away from this category and towards the more functioning category of "blues music", was also the man who found the Count Basie band in Kansas City and made it possible for them to record and sell records in the national marketplace. Unfortunately, along the way, however, he replaced the violin playing Williams with Freddie Green who did not double, but only played guitar.

Along with the ethnomusicological divide created by the "race music" term are also subconscious assumptions about instrumentation, including - but not limited to - the notion that the violin is not an instrument for use in "race music" and that therefore African American musicians and recording stars should not perform on the violin, and furthermore, that they should not use violin players in their supporting instrumentations and back-up bands. ${ }^{10}$ Thus Hammond probably assumed he was doing Basie a favor by cutting Williams, and in that way helping the band's sound to conform to industry and audience stereotypes of what an African American performing ensemble was supposed to sound like at the time.

Within the context of other great American musics as they are performed today in the deep south, Clarence "Gatemouth" Brown is not only a great jazz and blues fiddle player, but simply, as he says himself, a great fiddle player. Gate is lucky in that the music of western Louisiana and east Texas is still supported by a strong indigenous local market. For oddly enough, if white record buyers just to the north - in the regions around Kansas City - had not been sold (and sold out) to the notion that rock ' $n$ ' roll was a replacement for "race music", and that fiddle playing is inherently "white", the music industry and the public might have heard quite a bit more from Claude Williams over the years, and have retained a much better sense of the (inter)relationships between a variety of musical subcultures in the middle areas of the United States as well as in the deep south.

\section{Claude Williams and Chombo Silva: Sidemen par Excellence}

The careers of Claude "Fiddler" Williams in jazz, and Jose "Chombo" Silva in charanga, not only paralleled but also mirrored each other, in a way which for me offers one of the primary challenges for promoters of instrumental soloists in World

10 For one example of the inherent falseness of this assumption, see the film Louie Bluie (Terry Zwigoff, Pacific Arts Video 1985) about the legendary African American fiddle and mandolin player Howard Armstrong. 
Music; that is, how to structure a band around a soloist who is not also a natural bandleader, showman and businessman.

Both men came up on music scenes where big band performance was part of the marketplace and both men thrived early on, working in supporting roles for other musicians. But what does it mean to be a sideman? To assume that bassist Eddie Cole as a bandleader was also taking the bulk of the solos in the band that featured both Claude and Eddie's brother Nat, would obviously be a false assumption within the jazz context. Unfortunately for Claude, when the market bottomed out on swing music in the United States at the end of the 1940s, Claude had nowhere to go but the front (of the bandstand) and I think this was a difficult transition for him. For in addition to the assumptions about the lack of violin in the context of "race music", and while Claude was also a guitarist, jobs for jazz sidemen became scarcer and scarcer from the 1940s on. Therefore Claude was forced to struggle until the early 1970s, when Jay McShann decided to use him in his ensemble, which also featured wind and brass, on a regular basis.

Within the context of charanga music, based on structures in traditional Cuban music, which feature the violin only as a supporting instrument (violin solos are few and far between, for example, in the recorded works of Orqesta Aragon), Chombo Silva had a different problem from that of Claude Williams. For Cuban big band music, a.k.a. charanga was a craze in the Latin community of the New York metropolitan area until the beginning of the 1980s. Thus, while Chombo was working and performing constantly, we as listeners did not get nearly enough of a chance to experience his incredibly dynamic soloing chops - perhaps we would have had, had Chombo himself been more of a collaborator or leader and less of a sideman.

Thus, while Claude Williams is currently renowned as one of the great improvisers on his instrument, he did not get nearly enough chance to work during his lifetime. Chombo, on the other hand, worked an awful lot, but never really got the exposure or recognition he deserved for his spirited, energetic and innovative work as a solo performer. I think both of these men would have been better served by being regularly featured as soloists (perhaps taking $30-60 \%$ of the solos) in bands directed by other musicians, also capable of both fronting and backing their work.

The question raised is this: How can music promoters and producers support the work of great performing musicians, who do not possess talent for showmanship or for conducting a band, but whose improvising chops, like those of Claude and Chombo, are on a par with the greatest improvisers of all time? For I wish that Chombo Silva had had a Russ Dantzler to promote awareness of his incredible solo chops on a regular basis. I also wish that Claude Williams had had a high-energy working band of the caliber of Tipica Ideal or El Siglo Venti as a 
vehicle within which to showcase his chops on an ongoing basis during the years after he split from Jay McShann.

\section{Chombo Silva and Alfredo De La Fe: On the Side and Up Front}

The CD "Orchestra Rytmo Africa-Cubana" by Alfredo De La Fe ${ }^{11}$ has a copyright date of 1992 and no recording date. If I had to guess (and I might be wrong) it was probably recorded about a decade earlier. It features Sonny Bravo on piano, and a variety of other musicians from the 1970s salsa/ Latin jazz pantheon, of which Alfredo was such an important part. There are no pictures of Alfredo on the CD. The word charanga is not mentioned. Alfredo gets about 25 times as much solo time as a violin player ordinarily would on a recording of traditional charanga, but otherwise, regarding instrumentation and arrangement, it is absolutely unfusionlike and not even really in the direction of Latin jazz.

Alfredo is clearly the star of the music, and yet on the CD cover he is listed eighth on the personnel list, in between the guiro player and the coro singers. Why is this? For the sake of charanga audiences it is as if the whole notion of long extended violin solos, or a violin playing star, was being played down. Why does the word charanga not appear on the CD cover? Perhaps because, for non-Latin audiences, for whom the charanga instrumentation is unfamiliar and for whom charanga might seem at first glance to be too European a syncretism, the title "Rytmo Africa-Cubana", might sell records that could also be enjoyed by jazz and rock heads, also for the surprising strength of the extended violin solos.

In any case, based on my discussion of Chombo Silva above, and of the idiosyncracies of the market within which Alfredo was trying to promote his sounds at the end of the 1970s and the beginning of the 1980s I think that his (second) exile period, the time that he spent in Colombia and Europe (from the 1980s to the beginning of the new millenium) gave Alfredo the kick he needed to develop his business and band fronting chops. To the audiences he was foreign anyway, so it did not matter that he was breaking what was essentially a taboo; that of having a violin player as both the leader and the star of a charanga band. And Colombia and Europe being completely different exercises, Alfredo was able to develop different organizational strategies in both places, which will hopefully be useful for him in New York in reaching both Latin and non-Latin audiences.

Alfredo arrived in Colombia already a star within the context of Cuban music, which is admired in Colombia, and was able to set up shop as a band leader. This may have been more difficult in New York, both because of the huge number of stars

11 CD: Orchestra Rytmo Africa-Cubana; Alfredo De La Fe. 7779. 1992, vol. 1. 
ahead of him in line, but also because the New York charanga scene was already old and rules-bound in a way which made it difficult for a violinist to front a band. In Colombia, Alfredo was free to step out and lead his own groups, and to present his vision of violin-led charanga, in much the same way as $L$. Shankar needed to be in America before he could be comfortable in front of an ensemble performing carnatic music. In Colombia Alfredo performed both Cuban music and fusions of Cuban and Colombian music, and since audiences in Colombia were already great fans of his work, it would have been easy enough for him to work on his band-leading chops, because gigs and recording sessions were readily available.

In Europe, a non-Latin market, where most audiences are unfamiliar with the notion of charanga and thus with the idea of the violin as an inherent component of Afro-Cuban music, Alfredo could then take his band-leading chops from his Colombia days and work on his promotion skills, presenting a musical package, which to European brains may have been a little unfamiliar, even if the sounds, once successfully showcased, were recognizable enough.

Ironically, while a musician like Gatemouth Brown, who was lucky enough to come up in a local music scene (that was also a self-sustaining marketplace for his whole life), could make the organic transition from sideman to collaborator to the great band leader (that he has been for the last 30 years or so), Alfredo De La Fe has had the (mis?)fortune to be cast about like a latter day Odysseus. After starting out in Cuba, Alfredo worked in New York from the late 1960s to the early 1980s, and later in Colombia and Italy. Throughout the course of his multi-faceted international journey, Alfredo has been picking up musical, business and production skills, thus becoming the leader that he is today. Chombo, in contrast, with his mild-mannered social intelligence, made it as a full-time sideman even though he possessed the best solo improvisation chops of any violinist in any music of his generation.

\section{Shankar and Simon Shaheen: Traditions and Fusions}

The work and work styles of L. Shankar and Simon Shaheen clarify the point that I earlier made about dynamism of the traditional musical forms and of successful fusions. While Shankar has proven to the Western audiences that carnatic music is a living, growing and dynamic musical form, Simon Shaheen, in his work with The Near East Music Ensemble, has done the same for classical Arabic music. With his group Qantara, Shaheen takes a step further and integrates his traditional Arabic sounds into a format that is at times reminiscent of the group Oregon, at other times of work done in the past by Paco De Lucia, Al Dimeola and Larry Coryell, and yet at other times inspiring in a completely unique way, while never leaving the path of great Arabic classical sounds far behind. 
Joe Boyd (in this volume) discusses the problems inherent in the promotion of fusions in World Music, and what happens when people with non-Western musical backgrounds end up in studios, wishing to create Western-sounding music with Western instruments, hardware and software, with which they might not be entirely literate. However, the work of truly great artists, such as Shankar and Shaheen, proves that any new fusion is a creative experiment, and one cannot know in advance whether the experiment succeeds or fails.

Experimentations of Shankar and Shaheen have paid off handsomely. Their instrumental and technical choices are interesting, too; while Shankar performs his variations of the ancient traditions of carnatic music on a ten-string double-neck electric violin, invented and designed by guitar builder and engineer Ken Parker, Shaheen works his fusions on a 1773 Gagliano violin and a 1920 Nahat Oud. ${ }^{12}$ This proves that in the hands of an able performer, who makes personal choices that enhance his personal strengths rather than expose his limitations, a piece of hybrid twentieth century electronic American hardware can support the creation of and innovation upon ancient South Indian classical sounds. Equally well, classical hardware in the right hands, such as Shaheen's, can be used to celebrate new blends of music for the benefit of listeners and performers alike. The task of music industry professionals then is to support performers in reinforcing their strengths on the bandstand and in expanding their horizons in the practice room.

\section{Conclusion: World Music and the Promotion of Live Sounds in Turbulent Times}

In his conference presentation John Hutnyk (see this volume) indicated that even to discuss music at a time of global terror and of the demonization of the Asian minority populations across Europe is frivolous. However, I believe that within the seed of the notion World Music lies a possibility for response rather than reaction to both religious totalitarianism and the machinations of the military-industrial complex.

Simon Shaheen is Palestinian. L. Shankar is an Indian who spent his early childhood in Jaffna, Sri Lanka, until the family's house was burned down, and several attempts were made on his father's life during the communal violence of 1953, making the family to flee back to India. Alfredo De La Fe was born in Cuba several years before Castro came to power and was studying classical music in Warsaw as a young teenager in 1964, when he chose (for whatever reason) to relocate to the United States.

12 CD: Blue Flame. Liner Notes. 
If we followed Hutnyk's thinking of politics and music, all three of these artists should rather have dedicated themselves to advancing the political struggle against oppression and for the advanced forms of socialism and democracy. I would argue, on the contrary, that these three great artists, coming out of "timeless" traditions, possessing great technical skill and performance energy, and armed only with a simple piece of baroque era European folk technology, the violin, are in fact the advanced guard in the fight against cultural imperialism. And that if we sacrifice the notion of great art in favor of some universal, unified political monoculture, in the end we are doing as much damage to ourselves as if we allow the "invisible hand" of the "free" market to determine not only our musical choices, but also the subconscious assumptions, which determine them.

The job of the World Music industry then is to support the work of great musicians like the ones discussed in this article. Producers, promoters and managers should acknowledge the individual expertise, values and strength areas of the musicians in order to enable them to contribute to and experiment with different musical traditions in the best possible way. This involves finding out where a musician is coming from in terms of professional, musical and social intelligence and supporting him or her in finding the most suitable role or combination of roles on the bandstand and in the recording studio. 


\section{References}

Baldwin, James 1955. Notes of a Native Son. Boston: Beacon Hill Press.

Boyd, Joe 2009. Traditional Music and the World Music Marketplace: A Producer's Experience. In this volume.

Crouch, Stanley 2005. "The Colossus: When Sonny Rollins is at His Best", The New Yorker Magazine, May 9.

Hansen, Annette 2004. Writing Indigenous Belonging: Ownership in the Construction of Identity in Japan. In Flemming Christiansen \& Ulf Hedetoft (eds.) The Politics of Multiple Belonging. London and Burlington: Ashgate Press. 221-238.

Hutnyk, John 2009. Diasporic Music in a Time of War. In this volume.

Peraza Álvarez, Ernesto "Chico" 2001. "Chombo Silva: A Tribute to the Magician of Baracoa". New York City: Latin Jazz Network -webpage. Translated version: $<$ http://www. latinjazznet.com/articles/chombo_silva.htm >>.

Said, Edward 1979. Orientalism. New York: Vintage.

\section{Internet Sources}

Brown, Clarence Gatemouth: biography. $<<h t t p: / / w w w . g a t e m o u t h . c o m / b i o . h t m>>$.

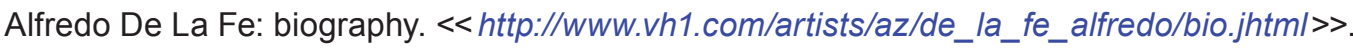

European Jazz Network Musicians: Alfredo De La Fe Violin, Duende. $<$ «ttp://www.ejn.it/mus/ delafe.htm >>.

Toca Alfredo: Alfredo De La Fe: violinist Alfredo De La Fe is back with beautiful music and a message. Varela, J. reprinted: Latin Beat Magazine. March 2003. Looksmart. $<<$ http:// www.findarticles.com/p/articles/mi_m0FXV/is2_13/ai_100731482/print >>.

Simon Shaheen: biography, AOL Music. $\ll$ http://music.channel.aol.com/artist/main. adp?tab=bio\&artistid $=3432>>$.

Simon Shaheen: Maqam Arabic Music. $<$ http://www.maqam.com/artists/shaheen.shtm/ .

Simon Shaheen: Global Village Idiot. <<http://www.globalvillageidiot.net/shaheen.htm >>.

Simon Shaheen: Concert Schedule: The Near East Music Ensemble. $\ll$ http://www. heartheworld.org/touring/upcoming/SimonShaheen >>.

Shankar L.: Profile. Underwood, L. Reprinted from Downbeat Magazine. November 2nd, 1978. 《<http://www.cs.cf.ac.uk/Dave/mclaughlin/art/shankar.htm/>>.

Shankar L.: Wikipedia the free encyclopedia. 《<http://en.wikipedia.org/wiki/L._Shankar $\gg$.

Claude "Fiddler" Williams: biography. AOL Music. $<$ http://music.channel.aol.com/artist/main. adp?tab=bio\&artistid $=138072>>$.

Claude Williams biography: Excerpted from progressive CD Liner Notes, 1995. $<$ http://shoko. calarts.edu/ chung/artists/ClaudeWilliamsbio.htm/>>.

"Visionary Violinist", Hinduism Today, March/April 2001. «<http://www.hinduism-today.com/ archives/2001/3-3/19_1_shankar.shtm/>>. 


\section{CDs, DVDs, and Films:}

CD Blue Flame. Shaheen, S. \& Qantara. Ark 21 Records. 2001.

CD Garland. Subramaniam, Dr. L. \& Asmussen, S. Storyville Records. 1978/2000.

CD Orchestra Rytmo Africa-Cubana; Alfredo De La Fe. 7779. Vol.1, 1992.

CD Live at J's Part 1. Williams, C. Arhoolie Records. 1993.

DVD Clarence "Gatemouth" Brown Live In New Orleans. Brown, C.G. Track 11: Up Jumped The Devil. Trad. Storyville Records, 1984.

Film: Louie Bluie. Armstrong, H., Zwigoff, T. Pacific Arts Video, 1985. 